\title{
Effect of the Ni/Al ratio of hydrotalcite-type catalysts on their performance in the methane dry reforming process
}

\author{
F. Touahra ${ }^{1,2} \cdot$ M. Sehailia ${ }^{2} \cdot$ W. Ketir ${ }^{3} \cdot$ K. Bachari ${ }^{2} \cdot$ R. Chebout ${ }^{2} \cdot$ \\ M. Trari ${ }^{3} \cdot$ O. Cherifi ${ }^{1} \cdot$ D. Halliche ${ }^{1}$
}

Received: 19 February 2015/ Accepted: 8 May 2015/Published online: 5 June 2015

(c) The Author(s) 2015. This article is published with open access at Springerlink.com

\begin{abstract}
Hydrotalcite-type solids of the form NiAl- $R$, where $R$ refers to the ratio of $\mathrm{Ni}$ to $\mathrm{Al}(R=2,3,5,8$, and 10$)$, were successfully synthesized following co-precipitation method at $\mathrm{pH}=12$. The obtained solids were calcined at $800{ }^{\circ} \mathrm{C}$, except for NiAl- $R_{2}$ where calcination was performed at temperatures ranging between 300 and $800{ }^{\circ} \mathrm{C}$. Following calcination, the resulting materials were evaluated for their catalytic activity and stability during the process of dry reforming of methane. Factors affecting the catalytic activity of the obtained materials such as the ratio $R$ and calcination temperature were also studied. Prior to calcination, X-ray diffraction analyses clearly illustrated the typical hydrotalcite structure of the synthesized materials (when $R \leq 5$ ). On the other hand, calcination at various temperatures prompted decomposition of all solids to form $\mathrm{NiO}$, with exception to $\mathrm{NiAl}-R_{2}$, which upon calcinations at $800{ }^{\circ} \mathrm{C}$ was decomposed to form $\mathrm{NiO}$ and a second phase spinel containing $\mathrm{NiAl}_{2} \mathrm{O}_{4}$. The chemical composition of the obtained solids was determined by atomic absorption spectroscopy. Further characterization was performed using several techniques, including: surface area measurements $\left(S_{\mathrm{BET}}\right)$, scanning electron microscopy, Fourier transform infrared spectroscopy and thermogravimetric analysis. The
\end{abstract}

K. Bachari

bachari2000@yahoo.fr

1 Laboratory of Natural Gas Chemistry, Faculty of Chemistry, USTHB, BP 32, 16111 Algiers, Algeria

2 Centre de Recherche Scientifique et Technique en Analyses Physico-Chimiques, CRAPC, BP 248, 16004 Algiers, Algeria

3 Laboratory of Storage and Valorization of Renewable Energies, Faculty of Chemistry, USTHB, BP 32, 16111 Algiers, Algeria reducibility of nickel species was studied via temperatureprogrammed reduction. The catalytic performance of the asprepared samples was studied for dry reforming of methane under atmospheric pressure at temperatures ranging between 400 and $700{ }^{\circ} \mathrm{C}$. The catalytic activity of the designed substances highlighted the importance of molar ratios i.e. $\mathrm{Ni}^{2+}$ / $\mathrm{Al}^{3+}$ on the success of the overall dry reforming of methane process. The catalytic activity of the synthesized materials was also found to be directly proportional to the ratio of $\mathrm{Ni} /$ $\mathrm{Al}$ as well as the calcination temperature, with exception to NiAl- $R_{2}$ which was found to exhibit the highest activity of all. The latter observation was perhaps associated with the lower size of the crystalline particles in conjunction with the presence of a second phase containing $\mathrm{NiAl}_{2} \mathrm{O}_{4}$. In this study, it is shown that the calcination temperature has a significant effect on the catalytic property and the crystallite size of the metal.

Keywords Dry reforming of methane $\cdot$ Hydrotalcite-like compound $\cdot$ Nickel $\cdot$ Hydrogen

\section{Introduction}

The development of novel metal-based complexes as catalysts for the production of synthesis gas via the process of dry reforming of methane (DRM) had attracted the attention of many environmental chemists in the past decades. DRM is considered as an eco-friendly process due to the consumption of two greenhouse gases, namely carbon dioxide and methane [1]. A feedstock gas mixture with low $\mathrm{H}_{2} / \mathrm{CO}$ ratio is preferentially used for the production of liquid hydrocarbons in the Fischer-Tropsch synthesis [2]. Previously, DRM reactions were catalyzed by group VIII transition metals such as $\mathrm{Ni}, \mathrm{Rh}, \mathrm{Ru}, \mathrm{Pd}, \mathrm{Pt}, \mathrm{Ir}$ and $\mathrm{Co}$ [3]. 
Despite current debates in relation to the order of activity of group VIII elements in DRM reactions, Rh was always elected as the catalyst of choice by most chemists. However, nickel was also reported as a very active metal for this reaction despite being deactivated by the formation of carbon $[4,5]$, since the reforming process is a relatively highly endothermic reaction (Eq. 1) [6, 7]. The formation of carbon is mainly produced by methane decomposition (Eq. 2) and carbon monoxide disproportionation (Boudouard reaction) (Eq. 3).

$$
\mathrm{CH}_{4}+\mathrm{CO}_{2} \Leftrightarrow 2 \mathrm{CO}+2 \mathrm{H}_{2} \Delta \mathrm{H}^{0}=+247.0 \mathrm{~kJ} \mathrm{~mol}^{-1}
$$

$$
\begin{aligned}
& \mathrm{CH}_{4} \Leftrightarrow 2 \mathrm{H}_{2}+\mathrm{C} \Delta \mathrm{H}^{0}=+75 \mathrm{~kJ} \mathrm{~mol}^{-1} \\
& 2 \mathrm{CO} \Leftrightarrow \mathrm{CO}_{2}+\mathrm{C} \Delta \mathrm{H}^{0}=-173 \mathrm{~kJ} \mathrm{~mol}^{-1}
\end{aligned}
$$

The lower price and availability of nickel still provide an incentive for its continual utilization as a catalyst of choice, when compared to other noble metals. On the other hand, the generation of carbon can be reduced following the utilization of specific methods such as high dispersion of metal species over the surface area of the catalyst and incorporation of alkaline earth metal oxides within the catalyst in order to minimize coke formation $[8,9]$. Following robust preparation procedures in conjunction with the addition of a suitable noble metal to the nickel-based catalyst, such as $\mathrm{Pt}, \mathrm{Ru}$ and $\mathrm{Rh}$, can also determine the success of a DRM reaction.

The incorporation of $\mathrm{Ni}^{2+}$ ions within well-defined structures, such as perovskites [10,11] and spinels [12], was also shown to increase the activity and catalytic stability via inhibiting the formation of carbon in DRM reactions. Other previously studied catalytic systems, such as those derived from layered double hydroxides (LDHs) that contain large surface areas, can result in the formation of homogeneous mixture of oxides with small crystal sizes. Reduction of LDHs prompts the formation of small, thermally stable, metal particles that can minimize the sintering of the nickel catalyst and enhance chemisorption of carbon dioxide [13], thus, avoiding the formation of coke [14, 15].

Layered double hydroxides (LDHs), or hydrotalcite-like compounds (HTLCs), are a family of compounds that have attracted considerable attention in recent years [16, 17]. Their structure can be derived from the brucite form of $\mathrm{Mg}(\mathrm{OH})_{2}$, where each $\mathrm{Mg}^{2+}$ ion is octahedrally surrounded by six $\mathrm{OH}^{-}$ions. The hydrotalcite-type (HT) structure is obtained when some $\mathrm{Mg}^{2+}$ ions, or other divalent cations, are replaced by trivalent cations, with similar atomic radius (r) to $\mathrm{Mg}^{2+}(r=0.65 \AA$ A $)$ [18]. This substitution creates a positive charge in the hydroxide layer, which is compensated by interlayer anions and water molecules [19]. For this reason, they are also known as anionic clays. The general formula of LDHs is $\left[\mathrm{M}_{1-\mathrm{x}}^{2+} \mathrm{M}_{\mathrm{x}}^{3+}(\mathrm{OH})_{2}\right] \mathrm{A}_{\mathrm{x} / \mathrm{n}}^{\mathrm{n}-}, \mathrm{mH}_{2} \mathrm{O}$, where $\mathrm{M}^{2+}$ and $\mathrm{M}^{3+}$, respectively, stand for divalent and trivalent cations. $\mathrm{A}^{\mathrm{n}-}$ is an exchangeable interlayer anion [16] while $x$ is the charge density of the layer which equals to the molar ratio of $\mathrm{M}^{2+} /\left(\mathrm{M}^{2+}+\mathrm{M}^{3+}\right)$.

It has been established $[20,21]$ that pure hydrotalcites can only be formed with stoichiometries in the range $0.2<x<0.33$. Higher values of $x(>0.33)$ may lead to the formation of $\mathrm{Al}(\mathrm{OH})_{3}$, usually undetected by PXRD; such occurrence is due to the increase of neighboring $\mathrm{Al}^{3+}$ octahedral. Similarly, lower values of $x(<0.2)$ may result in a high density of $\mathrm{Mg}^{2+}$ octahedral, hence the formation of $\mathrm{Mg}(\mathrm{OH})_{2}$.

Following the co-precipitation method, Zhao et al. [17] successfully synthesized precursors of $\mathrm{ZnNiFe}-\mathrm{LDH}$ with molar ratios $\mathrm{M}^{2+} / \mathrm{M}^{3+}$ between 0.5 and 4 i.e. $0.2<x<0.66$. XRD results showed that $\mathrm{ZnNiFe}-\mathrm{LDH}$, where $x=0.33,0.25$ and 0.2 , has pure hydrotalcite-like phase. When $x$ is large, e.g. $x=0.5$ and $0.66, \mathrm{NiFe}_{2} \mathrm{O}_{4}$ was obtained. However, several papers stated that LDHs can be formed with $x$ values outside the range $(0.2<x<0.33)$. For example, syntheses of pure lamellar phases were achieved with $0.15<x<0.34$ in Mg/Al LDHs [22]; other LDHs have been obtained with reported values of $x$ lower than $0.07\left(\mathrm{Mg} / \mathrm{Ga}-\mathrm{CO}_{3}\right)$ [23] or higher than 0.5 for $\mathrm{Fe}^{2+} /$ $\mathrm{Fe}^{3+}$ LDHs [24]. Sometimes, the exact value of $x$ can be challenging to estimate in hydrotalcite-like compounds; chemical analysis only provides limited information related to the metal content of all solids. The presence of metal oxides and/or metal hydroxides in LDHs, in addition to high or low molar ratios of $\mathrm{M}^{2+} / \mathrm{M}^{3+}$, may give rise to certain anomalies in the values of $x$ [25].

LDHs can be synthesized by various methods depending on the specific requirement and properties of the desired compounds. However, co-precipitation is the most common synthetic process currently followed by chemists. LDHs have various widespread applications in a number of areas; they are used in catalysis [26], pharmaceuticals [27], chemical nanoreactors [28], photoactive materials, polymer additives [29, 30], environmental cleanup by ion exchange or adsorption processes [31], and in membrane technology [32].

Nickel-based LDHs have properties that make them suitable for preparing promising catalysts for dry reforming reactions. In this field, several research groups have investigated the utilization of $\mathrm{Ni} / \mathrm{Mg} / \mathrm{Al} \mathrm{LDH}$ as potential catalysts with high activity. Nickel sites are highly dispersed inside the LDHs' structures. Hence, following reduction, high catalytic performance should be achieved [33]. Tsyganok et al. [34] also investigated dry reforming of methane with catalysts of nickel-containing $\mathrm{Mg}-\mathrm{Al}$ LDHs; after $6 \mathrm{~h}, 95 \%$ conversion of methane and $98 \%$ 
conversion of carbon dioxide were attained. On the other hand, Zhang et al. [35] carried out dry reforming of methane in the presence of $\mathrm{Ni}-\mathrm{Mg}-\mathrm{Al} \mathrm{LDHs} / \gamma-\mathrm{Al}_{2} \mathrm{O}_{3}$ catalyst. $\mathrm{Ni}-\mathrm{Mg}-\mathrm{Al}$ catalysts, derived from $\mathrm{LDHs}$ and prepared in situ on $\gamma-\mathrm{Al}_{2} \mathrm{O}_{3}$, showed excellent catalytic properties in dry reforming of methane, compared to a reference catalyst containing $\mathrm{Ni} / \mathrm{MgO} / \gamma-\mathrm{Al}_{2} \mathrm{O}_{3}$ prepared by impregnation.

In the present work, a study was conducted to determine an adequate range of calcination temperature and molar ratios of $\mathrm{Ni}^{2+} / \mathrm{Al}^{3+}$ in order to obtain a nickel-based catalyst with high catalytic performance and small particles upon reduction. The results show that calcination temperatures and molar ratios $\mathrm{Ni}^{2+} / \mathrm{Al}^{3+}$ affect the reactivity and coke resistance of the metal particles, thus contributing to the overall catalytic process.

\section{Experimental}

\section{Preparation of precursors and catalysts}

Five samples of NiAl- $R$ where $R=2,3,5,8$, and 10 were synthesized following the co-precipitation method at $\mathrm{pH}=12$. All catalysts were prepared following the same procedure. Two aqueous solutions were prepared: solution 1 containing $\mathrm{Ni}\left(\mathrm{NO}_{3}\right)_{2} \bullet 6 \mathrm{H}_{2} \mathrm{O}$ (Biochem Chemopharma, $\geq 98 \%$ ) and $\mathrm{Al}\left(\mathrm{NO}_{3}\right)_{3} \cdot 9 \mathrm{H}_{2} \mathrm{O}$ (Biochem Chemopharma, $\geq 98 \%)$ at different concentrations, to obtain various ratios $R$; solution 2 containing $2.0 \mathrm{M} \mathrm{NaOH}$ (Panreac, $98 \%$ assay), and $0.4 \mathrm{M} \mathrm{Na}_{2} \mathrm{CO}_{3}$ (Panreac, $98 \%$ assay). Solution 1 was added dropwise to solution 2 under vigorous stirring at room temperature; the $\mathrm{pH}$ value was adjusted between 11 and 12 . The precipitate formed was dried at $80{ }^{\circ} \mathrm{C}$ in an oil bath shaker for $15 \mathrm{~h}$, then washed at ambient temperature using ultra-pure water to remove all residual salts. The resulting slurry was then dried overnight at $90{ }^{\circ} \mathrm{C}$ in dry oven.

The five samples obtained prior to calcination were assigned the following references: NiAl- $R_{2}, \mathrm{NiAl}-R_{3}$, NiAl$R_{5}, \mathrm{NiAl}-R_{8}$, and NiAl- $R_{10}$. Table 1 shows the different weights and concentrations utilized to synthesize hydrotalcites with different $R$ values. To investigate the phase change of the catalyst during the thermal decomposition process, $\mathrm{NiAl}-R_{2}$ was calcined at different temperatures i.e. $300,400,500,600,700$, and $800{ }^{\circ} \mathrm{C}$, for $6 \mathrm{~h}$. The samples were referred to as NiAl-T (NiAl-300, NiAl-400, NiAl-500, $\mathrm{NiAl}-600, \mathrm{NiAl}-700$, and NiAl-800). NiAl- $R$ calcined at $800{ }^{\circ} \mathrm{C}$ were referred to as follows: $\mathrm{NiAl}-R_{2}(800)$, NiAl$R_{3}(800), \mathrm{NiAl}-R_{5}(800), \mathrm{NiAl}-R_{8}(800)$, and $\mathrm{NiAl}-R_{10}(800)$. All samples were heated in increments of $5{ }^{\circ} \mathrm{C}$ per min and kept for $6 \mathrm{~h}$ at the ultimate calcination temperature.

\section{Catalysts characterization}

The chemical composition of each material was determined using atomic absorption spectroscopy (AAS) Varian spectra AA-110. The dissolution of solids was affected in the presence of nitric acid. Thermogravimetric analysis (TG) was carried out using Thermal Analyst (Setaram Set Sys 16/18) with temperatures ranging from 25 to $800{ }^{\circ} \mathrm{C}$ and heating increments of $5{ }^{\circ} \mathrm{C}$ per minute in the presence of air.

The crystal structure of the obtained solids was confirmed by XRD using two different apparatus, namely Siemens D5000 and Siemens D501 diffractometer equipped with a $\mathrm{Cu}-\mathrm{K}_{\alpha}$ radiation $(\lambda=0.15418 \mathrm{~nm})$; the data were collected in $2 \theta$ scan mode.

The average crystallite sizes of $\mathrm{Ni}^{0}$ following reduction were estimated using the Scherer equation:

$D_{\mathrm{hkl}}=\frac{0.9 \lambda}{\beta_{\mathrm{hkl}} \cos \theta}$

where $\lambda$ is the radiation's wavelength, $\beta_{\mathrm{hkl}}$ is the half width of the peak, and $\theta$ is the Bragg's diffraction angle.

The specific surface area was determined following BET measurements under nitrogen adsorption-desorption isotherms in a Micrometrics Tristar 3000. This apparatus was also used to estimate porous volumes as well as the size of pores following Barret-Joyner-Halenda (BJH) method. FTIR spectra were obtained with a Perkin-Elmer spectrometer in the region of $4000-400 \mathrm{~cm}^{-1}$ using $\mathrm{KBr}$ discs. The morphology of uncalcined samples was investigated using scanning electron microscopy (SEM) Jeol 320.

The calcined samples were analyzed by temperatureprogrammed reduction (TPR) TriStar 3000 V6.01, equipped with a TCD detector. $50 \mathrm{mg}$ of the catalyst was loaded

Table 1 Weights and concentrations used to synthesize NiAl- $R$

\begin{tabular}{lrrrr}
\hline $\mathrm{Ni} / \mathrm{Al}$ ratio & \multicolumn{1}{c}{$2: 1$} & $3: 1$ & $5: 1$ & \multicolumn{1}{c}{$8: 1$} \\
\hline Concentration of $\mathrm{Ni}\left(\mathrm{NO}_{3}\right)_{2} \bullet 6 \mathrm{H}_{2} \mathrm{O}(\mathrm{M})$ & \multicolumn{1}{c}{1} & \multicolumn{1}{c}{1} & \multicolumn{1}{c}{1} & \multicolumn{1}{c}{1} \\
Weight of $\mathrm{Ni}\left(\mathrm{NO}_{3}\right)_{2} \bullet 6 \mathrm{H}_{2} \mathrm{O}(\mathrm{g})$ & 29.08 & 29.08 & 29.08 & 29.08 \\
Concentration of $\mathrm{Al}\left(\mathrm{NO}_{3}\right)_{3} \bullet 9 \mathrm{H}_{2} \mathrm{O}(\mathrm{M})$ & 0.50 & 0.33 & 0.20 & 0.12 \\
Weight of $\mathrm{Al}\left(\mathrm{NO}_{3}\right)_{3} \bullet 9 \mathrm{H}_{2} \mathrm{O}(\mathrm{g})$ & 18.75 & 12.38 & 7.50 & 0.10 \\
\hline
\end{tabular}


into the reactor and flushed with helium for $1 \mathrm{~h}$ at $200{ }^{\circ} \mathrm{C}$. The temperature was lowered to room temperature and helium was replaced by $5 \%$ hydrogen gas in argon. After $1 \mathrm{~h}$ of flushing, the temperature was raised to $900{ }^{\circ} \mathrm{C}$ with increments of $10{ }^{\circ} \mathrm{C}$ per minute.

\section{Catalytic testing}

The catalytic tests were performed under atmospheric pressure, in a tubular fixed-bed quartz reactor (ID $=6 \mathrm{~mm}$ and $L=16 \mathrm{~cm}$ ), and placed in a furnace. The catalyst grains $(100 \mathrm{mg})$ were kept in place using quartz wool plugs. A thermocouple was placed on top of the catalyst's bed to measure the temperature. The furnace's temperature was controlled by a Eurotherm temperature controller. For comparison, all catalysts were reduced with pure hydrogen at $750{ }^{\circ} \mathrm{C}$ over a period of $1 \mathrm{~h}$. Following reduction, the temperature was lowered under argon to the initial reaction's temperature and a feed gas mixture containing $\mathrm{CH}_{4}: \mathrm{CO}_{2}:$ Ar in a ratio of 20:20:60. The total flow rate was

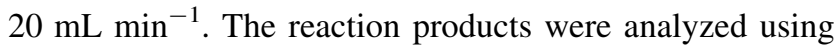
gas chromatograph (Delsi), equipped with a thermal conductivity detector (TCD) and Carbosieve B column, in the presence of carrier gas, argon.

Based on GC results, the conversion of methane, carbon dioxide, selectivity for hydrogen $\left(S_{\mathrm{H} 2}\right)$ and carbon monoxide $\left(S_{\mathrm{CO}}\right)$ production were calculated using the following formulae:

$$
\begin{aligned}
& (\%) \mathrm{CH}_{4} \text { conversion }=\frac{n_{\mathrm{CH}_{4}, \text { int }}-n_{\mathrm{CH}_{4}, \text { out }}}{n_{\mathrm{CH}_{4}, \text { int }}} \times 100 \\
& (\%) \mathrm{CO}_{2} \text { conversion }=\frac{n_{\mathrm{CO}_{2}, \text { int }}-n_{\mathrm{CO}_{2}, \text { out }}}{n_{\mathrm{CO}_{2} \text {,int }}} \times 100 \\
& S_{\mathrm{H}_{2}}=\frac{n_{\mathrm{H}_{2, \text { out }}}}{2 \times \mathrm{CH}_{4, \text { int }}-\mathrm{CH}_{4, \text { out }}} \times 100 \\
& S_{\mathrm{CO}}=\frac{\mathrm{CO}_{\text {out }}}{\left(\mathrm{CO}_{2, \text { int }}-\mathrm{CO}_{2, \text { out }}\right)+\left(\mathrm{CH}_{4, \text { int }}-\mathrm{CH}_{4, \text { out }}\right)} \times 100
\end{aligned}
$$

$$
\frac{\mathrm{H}_{2}}{\mathrm{CO}} \text { ratio }=\frac{S_{\mathrm{H}_{2, \text { out }}}}{S_{\mathrm{CO}, \text { out }}}
$$

where $n_{\mathrm{i}, \text { int }}$ and $n_{\mathrm{i} \text {, out }}$ are the molar flow rates of $i$-species.

\section{Results and discussion}

\section{Catalysts' characterization}

To determine the metal content of NiAl- $R$ catalysts, calcined at $800{ }^{\circ} \mathrm{C}$, atomic absorption spectroscopy (AAS) was used. The obtained results are depicted in Table 2. The results of the elemental analysis by AAS show that the molar ratios $\mathrm{Ni}^{2+} / \mathrm{Al}^{3+}$ are in good agreement with those calculated, taking into account the initial salt concentration. This confirms the quantitative precipitation of the precursor salt.

Thermal decomposition of the hydrotalcites was evaluated by TG. Typical TG curve of the hydrotalcite with $\mathrm{Ni} / \mathrm{Al}$ molar ratio of $2\left(\mathrm{NiAl}-R_{2}\right)$ is illustrated in Fig. 1.

The curve illustrates three distinct steps of mass loss, corresponding to three endothermic peaks. The first peak with mass loss of $4 \%$ occurring at about $87{ }^{\circ} \mathrm{C}$ is associated with the elimination of water, physically adsorbed on the external surface of the particle, [36] and $\mathrm{Ni}\left(\mathrm{NO}_{3}\right)_{2}$ decomposition, while the second peak at about $227{ }^{\circ} \mathrm{C}$ with mass loss of $6 \%$ may be attributed to the removal of $-\mathrm{OH}$ and water from the brucite-like layer as well as $\mathrm{Al}\left(\mathrm{NO}_{3}\right)_{3}$ decomposition. In the third peak, $14 \%$ of mass was lost up to $800{ }^{\circ} \mathrm{C}$, this could be due to the simultaneous removal of carbon dioxide from the decomposition of interlayer carbonate anions [37]. During this step, the destruction of the layered structure of the hydrotalcite and the formation of NiAl mixed-oxide structure occurred.

X-ray diffraction patterns for NiAl- $R(R=2,3,5,8$ and 10), prior to calcination, are illustrated in Fig. 2. A typical hydrotalcite-like type structure is present in all samples with $R \leq 5 \quad(x \geq 0.17)$. This is not clearly highlighted for samples with $R>5 \quad(x<0.17)$. The peaks observed for NiAl- $R_{2}, \mathrm{NiAl}-R_{3}$ and $\mathrm{NiAl}-R_{5}$ correspond to the layered double hydroxides structure Takovite [JCPDS file 15-0087]. XRD patterns for these catalysts showed several diffraction peaks at around $2 \theta=11.61^{\circ}, 23.30^{\circ}, 35.20^{\circ}, 39.55^{\circ}, 47.07^{\circ}, 61.24^{\circ}$, $62.63^{\circ}$, and $66.40^{\circ}$, indexed at $003,006,012,015,018$, 110,113 , and 116. Although XRD patterns for NiAl- $R_{8}$ and NiAl- $R_{10}$ displayed hydrotalcite-like phase as described above, an impurity phase around $2 \theta=51.93^{\circ}$ was also observed. This impurity shows that $\mathrm{Ni}(\mathrm{OH})_{2}$ [JCPDS file 14-0117] was obtained for lower values of $x$. A very low crystallinity was also observed for $\mathrm{Ni} / \mathrm{Al}$ ratio higher than five compared to the other samples. In most circumstances, the sharpness and intensity of XRD peaks is proportional to the crystallinity of the LDHs i.e. LDHs with a highly ordered structure. Previous studies have described the relationship between crystallinity and peak intensity or sharpness [38, 39]. Moreover, Fig. 2 shows that the peak intensity of LDH decreases with increasing Ni/Al ratio, which suggests the presence of lower aluminum content; this can result in a disordered LDH layer which can cause disorder in the LDH structure.

After calcination, the lamellar structure disappears and only $\mathrm{NiO}$ phase is observed at around $2 \theta=37^{\circ}, 44^{\circ}, 62^{\circ}$, $76^{\circ}$, and $79^{\circ}$ [JCPDS file 47-1049], for NiAl- $T$ ( $T=300$, $400,500,600$, and $700{ }^{\circ} \mathrm{C}$ ) as well as $\mathrm{NiAl}-R_{3}, \mathrm{NiAl}-R_{5}$, 
Table 2 Chemical compositions of catalysts NiAl- $R$, BET surface area $\left(S_{\mathrm{BET}}\right)$, surface area of the catalyst after reduction and $\mathrm{Ni}^{0} \mathrm{crystallite}$ size for all samples

\begin{tabular}{|c|c|c|c|c|c|c|}
\hline Catalysts & $\begin{array}{l}\text { Relative metal } \\
\text { composition }\end{array}$ & $\begin{array}{l}\mathrm{M}^{2+} / \\
\mathrm{M}^{3+}\end{array}$ & $\begin{array}{l}\text { Surface area }{ }^{\mathrm{a}}\left(\mathrm{m}^{2} \mathrm{~g}^{-1}\right) \\
\left(S_{\mathrm{BET}}\right)\end{array}$ & $\begin{array}{l}\text { Surface area }{ }^{\mathrm{b}}\left(\mathrm{m}^{2} \mathrm{~g}^{-1}\right) \\
\left(S_{\mathrm{BET}}\right)\end{array}$ & $\begin{array}{l}\text { Surface } \operatorname{area}^{\mathrm{c}}\left(\mathrm{m}^{2} \mathrm{~g}^{-1}\right) \\
\left(S_{\mathrm{BET}}\right)\end{array}$ & $\begin{array}{l}\text { Crystallite } \text { size }^{\mathrm{d}} \mathrm{Ni}^{\circ} \\
(\mathrm{nm})\end{array}$ \\
\hline $\begin{array}{l}\mathrm{NiAl}- \\
\quad R_{2}(800)\end{array}$ & $\mathrm{Ni}_{0.67} \mathrm{Al}_{0.33}-R_{2}$ & 2.03 & 90 & 120 & 119 & 6 \\
\hline $\begin{array}{l}\mathrm{NiAl}- \\
\quad R_{3}(800)\end{array}$ & $\mathrm{Ni}_{0.73} \mathrm{Al}_{0.27}-R_{3}$ & 2.70 & 111 & 124 & 70 & 18 \\
\hline $\begin{array}{l}\text { NiAl- } \\
\qquad R_{5}(800)\end{array}$ & $\mathrm{Ni}_{0.83} \mathrm{Al}_{0.17}-R_{5}$ & 4.88 & 93 & 119 & 95 & 15 \\
\hline $\begin{array}{l}\text { NiAl- } \\
\qquad R_{8}(800)\end{array}$ & $\mathrm{Ni}_{0.88} \mathrm{Al}_{0.12}-R_{8}$ & 7.33 & 110 & 123 & 101 & 12 \\
\hline $\begin{array}{l}\text { NiAl- } \\
\quad R_{10}(800)\end{array}$ & $\mathrm{Ni}_{0.90} \mathrm{Al}{ }_{0.10}-R_{10}$ & 9.00 & 109 & 121 & 114 & 8 \\
\hline NiAl-300 & $\mathrm{Ni}_{0.67} \mathrm{Al}_{0.33}-R_{2}$ & 2.03 & 90 & 236 & 40 & 24 \\
\hline NiAl-400 & $\mathrm{Ni}_{0.67} \mathrm{Al}_{0.33}-R_{2}$ & 2.03 & 90 & 184 & 42 & 24 \\
\hline NiAl-500 & $\mathrm{Ni}_{0.67} \mathrm{Al}_{0.33}-R_{2}$ & 2.03 & 90 & 156 & 60 & 22 \\
\hline NiAl-600 & $\mathrm{Ni}_{0.67} \mathrm{Al}_{0.33}-R_{2}$ & 2.03 & 90 & 156 & 90 & 20 \\
\hline NiAl-700 & $\mathrm{Ni}_{0.67} \mathrm{Al}_{0.33}-R_{2}$ & 2.03 & 90 & 132 & 101 & 13 \\
\hline NiAl-800 & $\mathrm{Ni}_{0.67} \mathrm{Al}_{0.33}-R_{2}$ & 2.03 & 90 & 120 & 119 & 6 \\
\hline
\end{tabular}

${ }^{a}$ Before calcinations

b After calcinations

c After reduction

${ }^{\mathrm{d}}$ From XRD measurements

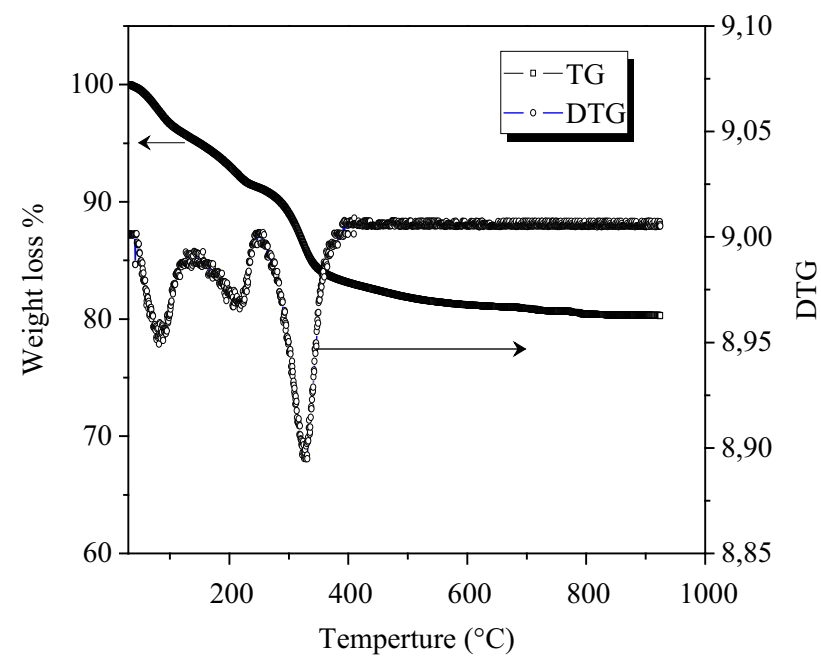

Fig. 1 TG analysis of NiAl- $R_{2}$

$\mathrm{NiAl}-R_{8}$ and NiAl- $R_{10}$ calcined at $800{ }^{\circ} \mathrm{C}$ (Fig. 3). Under such circumstances, the amorphous aluminum oxide phase would be formed but undetected by XRD; this is in agreement with other results previously reported in literature [33]. The spectrum of NiAl- $R_{2}$ sample calcined at $800{ }^{\circ} \mathrm{C}$ depicts two series of broad peaks corresponding to reflections close to those of $\mathrm{NiO}$ and $\mathrm{NiAl}_{2} \mathrm{O}_{4}$ spinel phases [39], where $2 \theta=19.14^{\circ}, 31.17^{\circ}$, and $37.56^{\circ}$ [JCPDS file 10-0339].

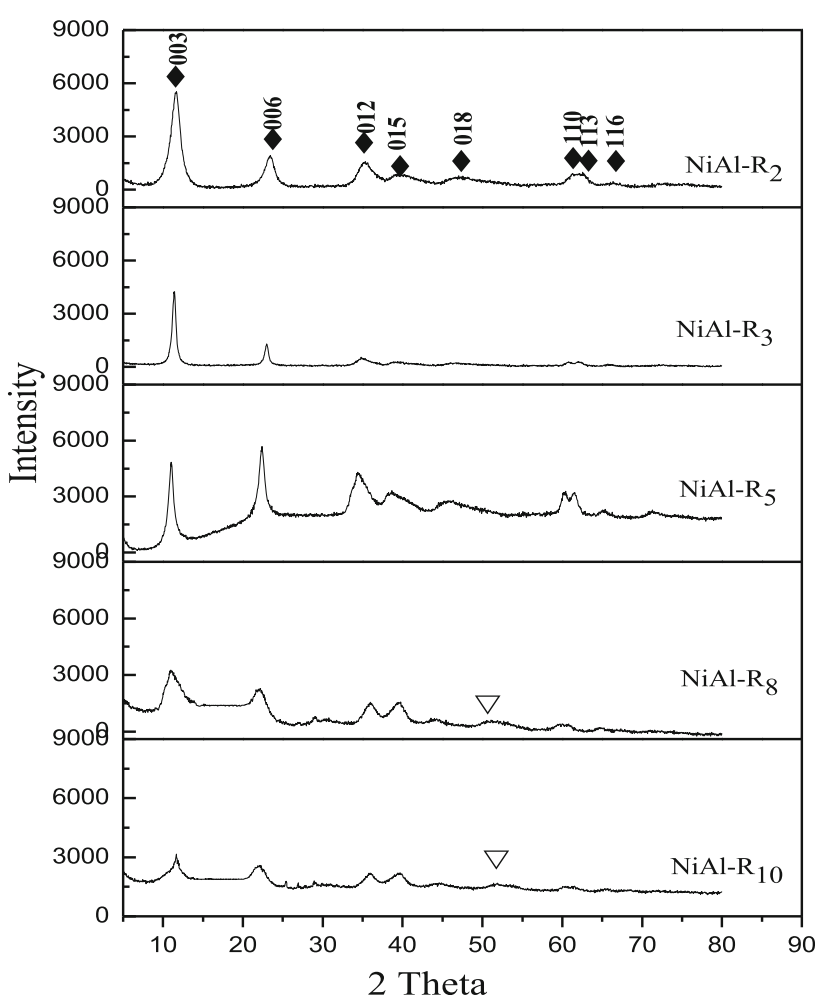

Fig. 2 XRD of the sample NiAl- $R(R=2,3,5,8$ et 10), filled diamond hydrotalcite, inverted triangle $\mathrm{Ni}(\mathrm{OH})_{2}$ 

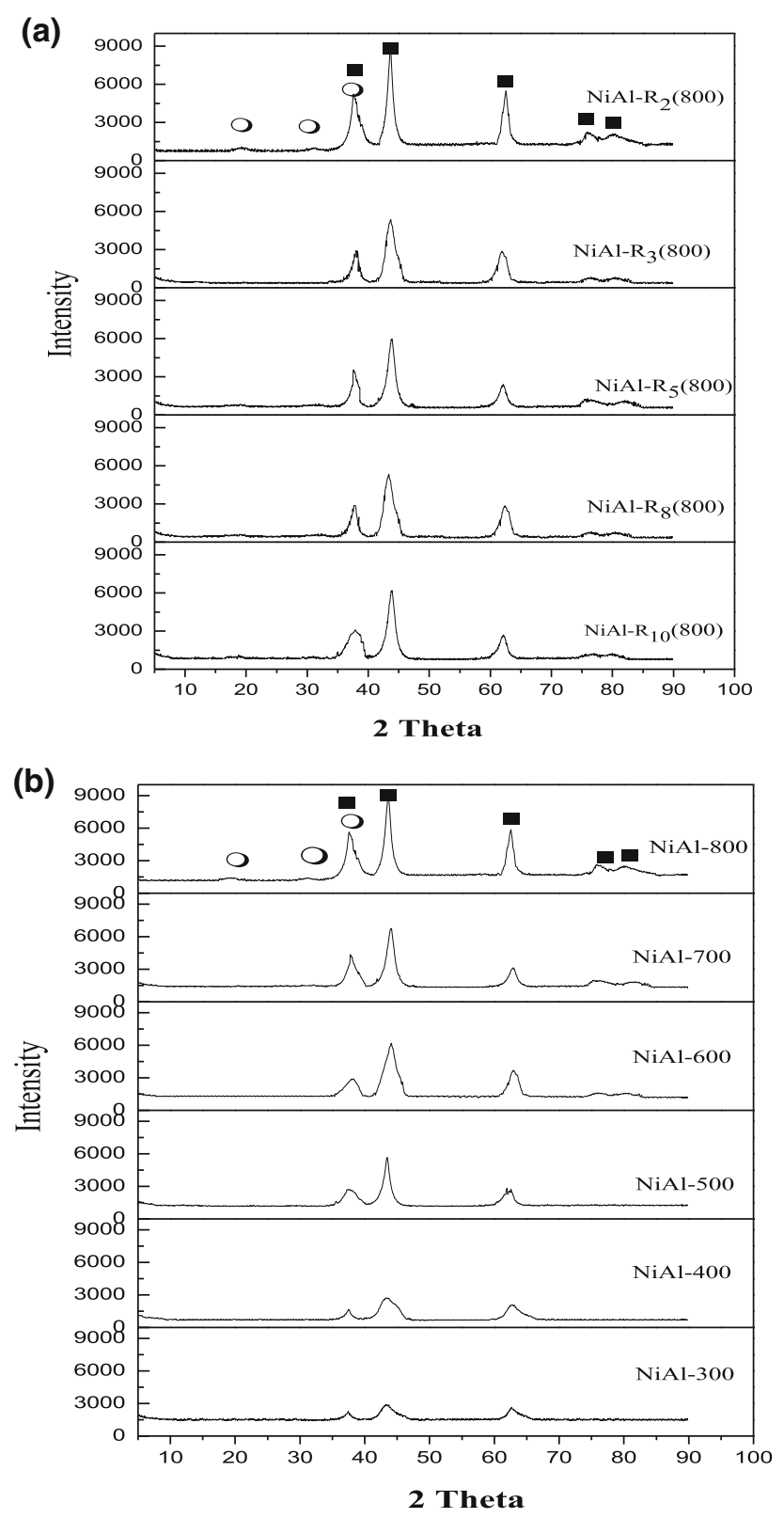

Fig. $3 \mathrm{X}$-ray diffraction patterns of: (a) NiAl- $R$ after calcinations at $800{ }^{\circ} \mathrm{C}$, and (b) NiAl- $T$ ( $T=300,400,500,600,700$ and $\left.800{ }^{\circ} \mathrm{C}\right)$. Filled square $\mathrm{NiO}$, empty circle $\mathrm{NiAl}_{2} \mathrm{O}_{4}$

XRD patterns of the reduced catalysts (prior to reaction) are provided in Fig. 4. After reduction at $750{ }^{\circ} \mathrm{C}$, the diffraction lines resulting from the formation of nickel metal phase located at $2 \theta=44.74^{\circ}, 51.41^{\circ}$ and $76.13^{\circ}$ [JCPDS file 04-0850] were also observed with $\mathrm{NiO}$, which decreased after reduction. The results indicate that a part of $\mathrm{NiO}$ was reduced to Ni metal. Very weak diffraction lines, due to a spinel phase of $\mathrm{NiAl}_{2} \mathrm{O}_{4}$, were also observed in $\mathrm{NiAl}-R_{2}(800)$. Table 2 shows the size of nickel particles calculated from DRX results, for solids reduced by means of Scherer equation. In all cases, $\mathrm{Ni}^{0}$ particle sizes obtained
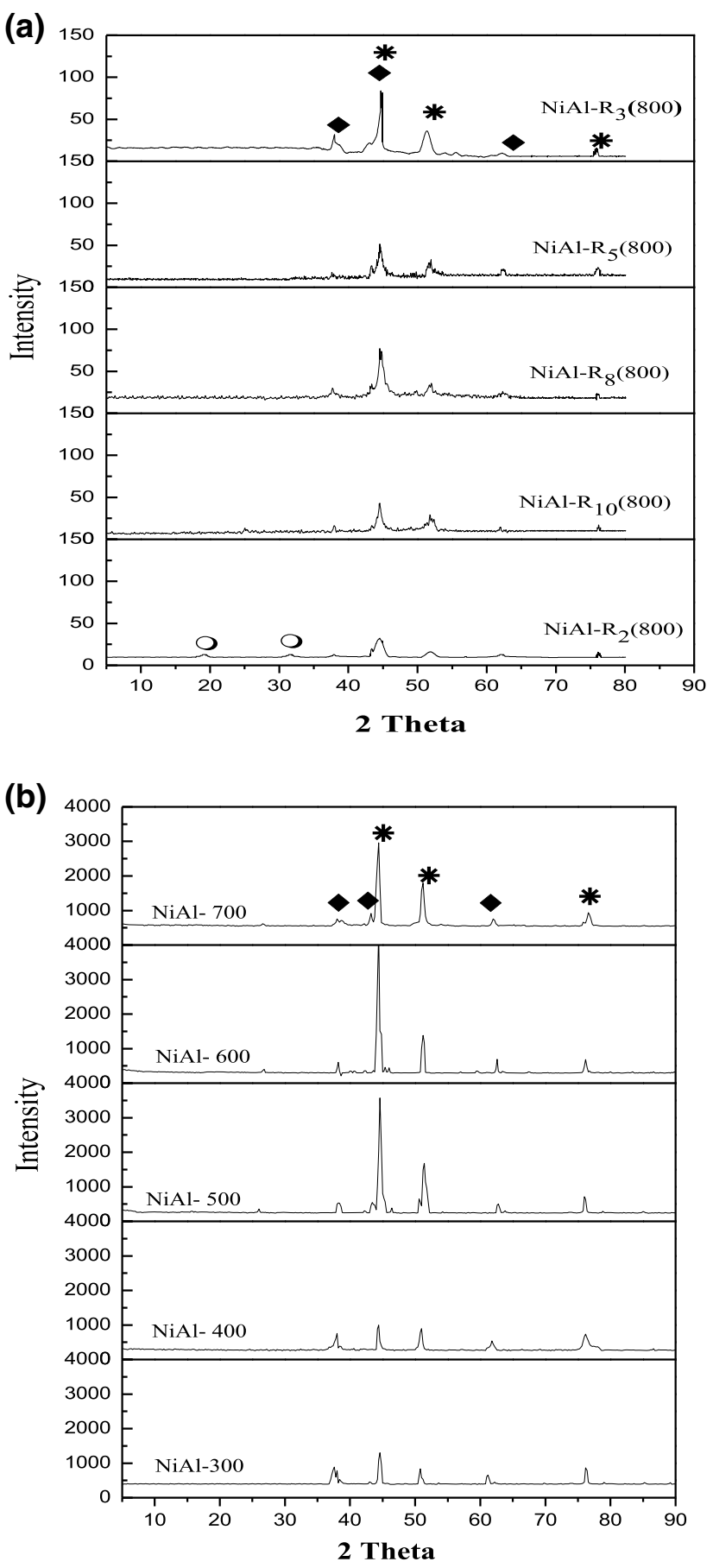

Fig. $4 \mathrm{XRD}$ for the reduced catalyst (a) NiAl- $R\left(800{ }^{\circ} \mathrm{C}\right)$ and (b) $\mathrm{NiAl}-T$. Empty square $(\mathrm{NiO})$, asterisk $\left(\mathrm{Ni}^{0}\right)$, empty circle $\left(\mathrm{NiAl}_{2} \mathrm{O}_{4}\right)$, at $750{ }^{\circ} \mathrm{C}$ with pure $\mathrm{H}_{2} ; 1.2 \mathrm{~L} / \mathrm{h}$

after reduction at $750{ }^{\circ} \mathrm{C}$ were between 6 and $24 \mathrm{~nm}$. When $R$ is greater than 2 , the intensity of the peaks assigned to $\mathrm{Ni}^{0}$ increases with decreasing the Aluminum content; thus, a reduction in the crystallite size is observed. Therefore, the crystallite size of nickel decreases in the following order: $\mathrm{NiAl}-R_{2}<\mathrm{NiAl}-R_{10}<\mathrm{NiAl}-R_{8}<\mathrm{NiAl}-R_{5}<\mathrm{NiAl}-R_{3}$. 


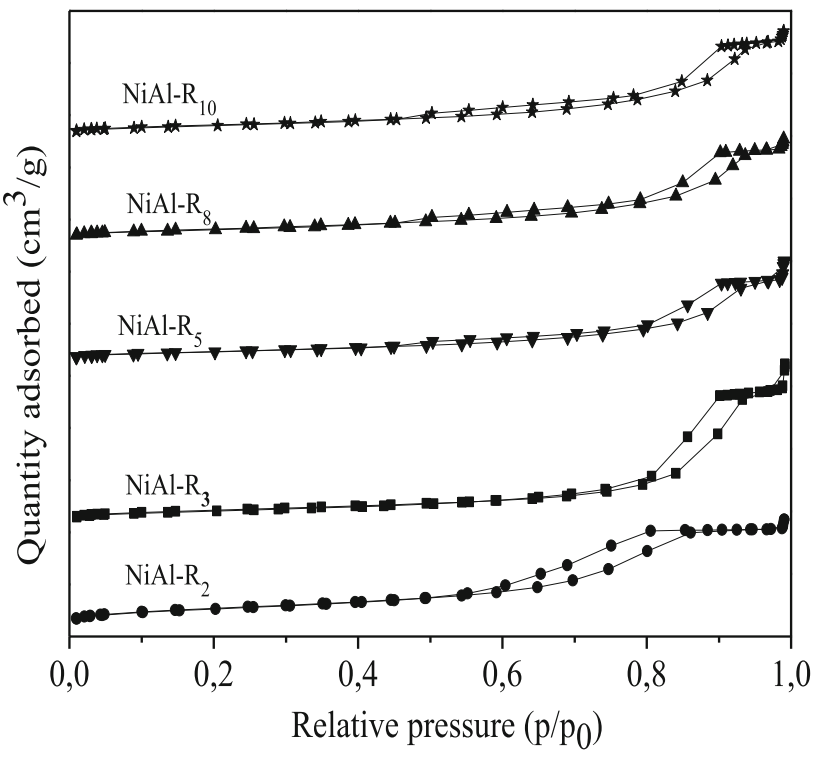

Fig. $5 \mathrm{~N}_{2}$ adsorption/desorption isotherms of NiAl- $R$

The textural properties of uncalcined NiAl$R\left(R=\mathrm{Ni}^{2+} / \mathrm{Al}^{3+}=2,3,5,8\right.$, and 10$), \mathrm{NiAl}-R$ calcined at $800^{\circ} \mathrm{C}$, and NiAl-T $(T=300,400,500,600,700$, and $800{ }^{\circ} \mathrm{C}$ ) are summarized in Table 2 . The specific surface of the uncalcined $\mathrm{NiAl}-R$ is relatively unchanged. It can be noticed that the surface area $\left(S_{\mathrm{BET}}\right)$ may be dependent of the nickel content. However, in a previous study, it was found that the surface area $\left(S_{\mathrm{BET}}\right)$ may be independent of the nickel content [40]. For NiAl-T, the surface area is sharply increased from $90 \mathrm{~m}^{2} \mathrm{~g}^{-1}$ to a value greater than $100 \mathrm{~m}^{2} \mathrm{~g}^{-1}$ after calcination. It was assumed that a porous structure is developed in the calcined sample during removal of water and carbonate from the interlayer space by the transformation of $\mathrm{CO}_{3}{ }^{2-}$ to $\mathrm{CO}_{2}$ [41-43]. The sample calcined at $300{ }^{\circ} \mathrm{C}(\mathrm{NiAl}-300)$ presents the highest surface area $\left(236 \mathrm{~m}^{2} \mathrm{~g}^{-1}\right)$, while $S_{\mathrm{BET}}$ value decreased gradually with increasing calcination temperature. The nitrogen adsorption/desorption isotherms of NiAl-R for the five solids exhibit type IV isotherms (Fig. 5) according to the International Union of Pure and Applied Chemistry (IUPAC classification), which are typical of mesoporous and slitshaped materials [44]. The samples also exhibit the hysteresis type $\mathrm{H}_{2}$ which is typical of clay minerals either of cationic or anionic types such as hydrotalcites [45].

FTIR spectra of NiAl- $R$ (uncalcined sample) are illustrated in Fig. 6a. Usually, these spectra show peaks which are typical of LDHs structure containing mainly carbonate anions $[33,46]$. IR spectra for all samples show similar absorption bands. The broadband at high frequency, i.e. around $3650 \mathrm{~cm}^{-1}$, is attributed to $\mathrm{O}-\mathrm{H}$ stretching vibration of water molecules and the hydroxyl groups of the brucitic layers. The absorption at $1645 \mathrm{~cm}^{-1}$ can be the result of $\mathrm{O}-\mathrm{H}$ bending vibration of water molecules in the interlayer space, while
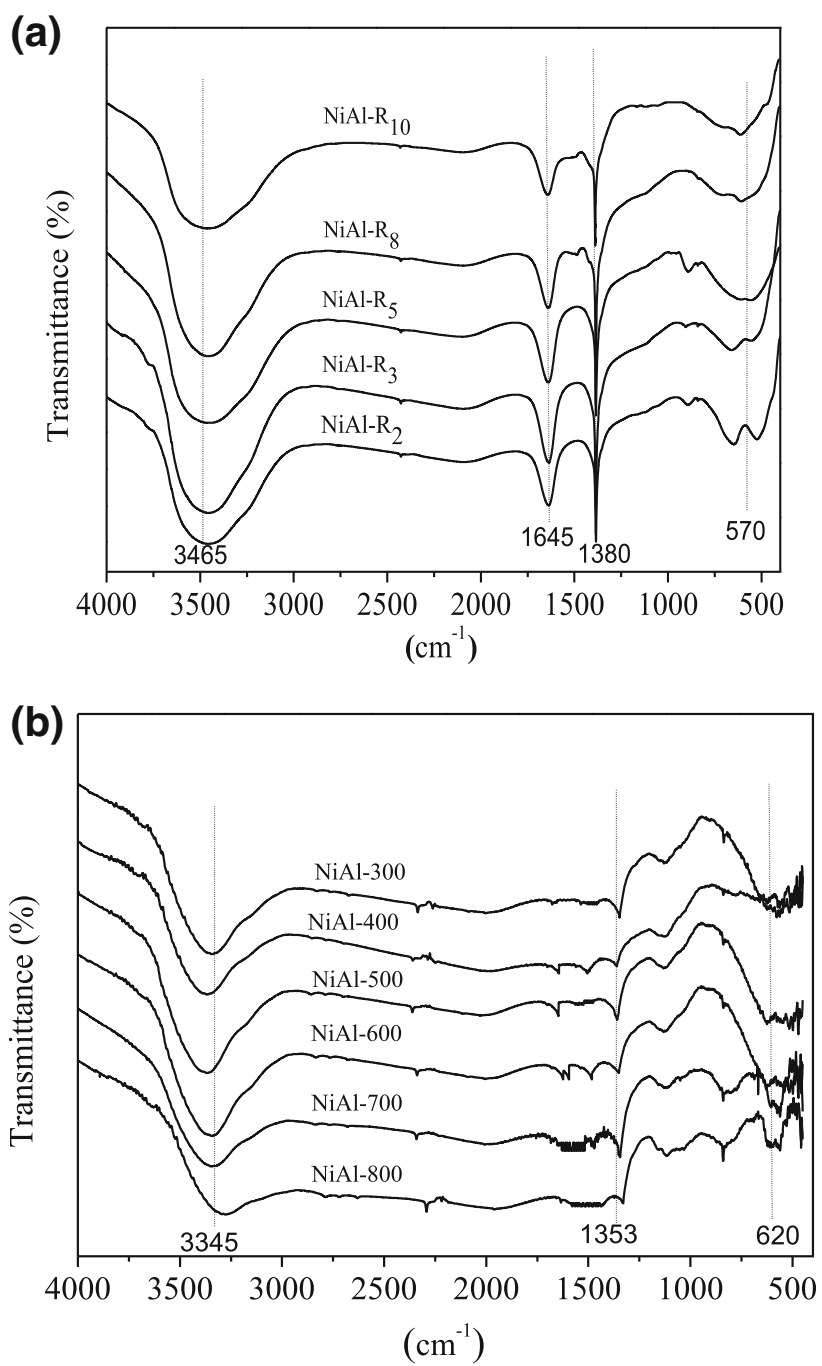

Fig. 6 The infrared spectrum of (a) NiAl- $R$ and (b) NiAl- $T$

the active adsorption band at $1380 \mathrm{~cm}^{-1}$ is a characteristic of $\mathrm{O}-\mathrm{C}-\mathrm{O}$ vibration of $\mathrm{CO}_{3}^{-2}$ in the interlayer space. The peak below $1000 \mathrm{~cm}^{-1}$ is attributed to metal-O-metal (Ni-O-Al) stretching mode [47, 48].

Compared to FTIR spectra of the uncalcined samples, phase transformations are observed after calcination, as shown in Fig. 6b. Trace amounts of the remaining carbonate were found around $1353 \mathrm{~cm}^{-1}$ after calcination at $300,400,500,600$ and $700{ }^{\circ} \mathrm{C}$, which then disappear after calcinations at $800{ }^{\circ} \mathrm{C}$. At $620 \mathrm{~cm}^{-1}$, the metal-oxygen (Ni-O and/or Al-O) stretching mode was observed. The result suggests the transformation of the crystal phase to mixed oxides; this is in a good agreement with our XRD data.

The morphology of NiAl- $R$ samples, prior to calcination, was investigated by SEM. From Fig. 7, the images of $\mathrm{NiAl}-R$ reveal that the studied solids consist of relatively uniform hexagonal platelet-like sheets; the hexagonal morphology is the characteristic of hydrotalcite materials. 
Moreover, when $\mathrm{Ni}^{2+} / \mathrm{Al}^{3+}=8$ and 10 , the solids are composed of crystals with irregular shapes. This observation is in agreement with the result obtained with XRD analysis.

Figure 8a presents the temperature-programmed reduction (TPR) analysis of NiAl- $R$ calcined at $800^{\circ} \mathrm{C}$. For $\mathrm{NiAl}-R_{3}\left(800{ }^{\circ} \mathrm{C}\right)$, two reduction peaks were obtained.
According to previous work [33], the first reduction peak at $360{ }^{\circ} \mathrm{C}$ could be attributed to the reduction of $\mathrm{NiO}$ which is weakly interacting with $\mathrm{Al}_{2} \mathrm{O}_{3}$ (undetected by XRD). The second peak at $776{ }^{\circ} \mathrm{C}$ is related to the reduction of $\mathrm{Ni}^{2+}$ to $\mathrm{Ni}^{0}$ in pure $\mathrm{NiO}[39,48]$. In another work by Perez-Lopez [40], it was suggested that in catalysts containing $\mathrm{Ni} / \mathrm{Mg} / \mathrm{Al}$, when the ratio of $\mathrm{Ni} / \mathrm{Mg}$ was
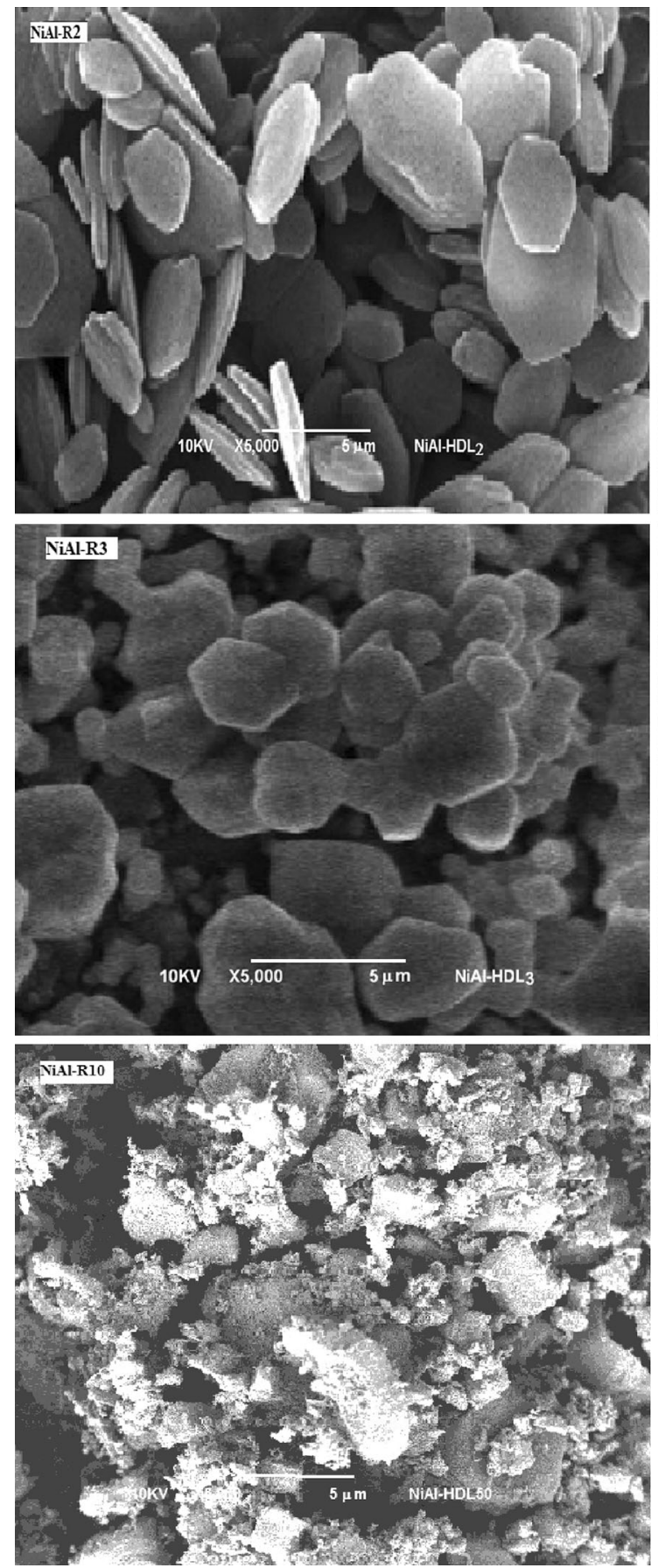

Fig. 7 SEM micro graph of NiAl- $R$ uncalcined (scale bar $5 \mu \mathrm{m}$ )
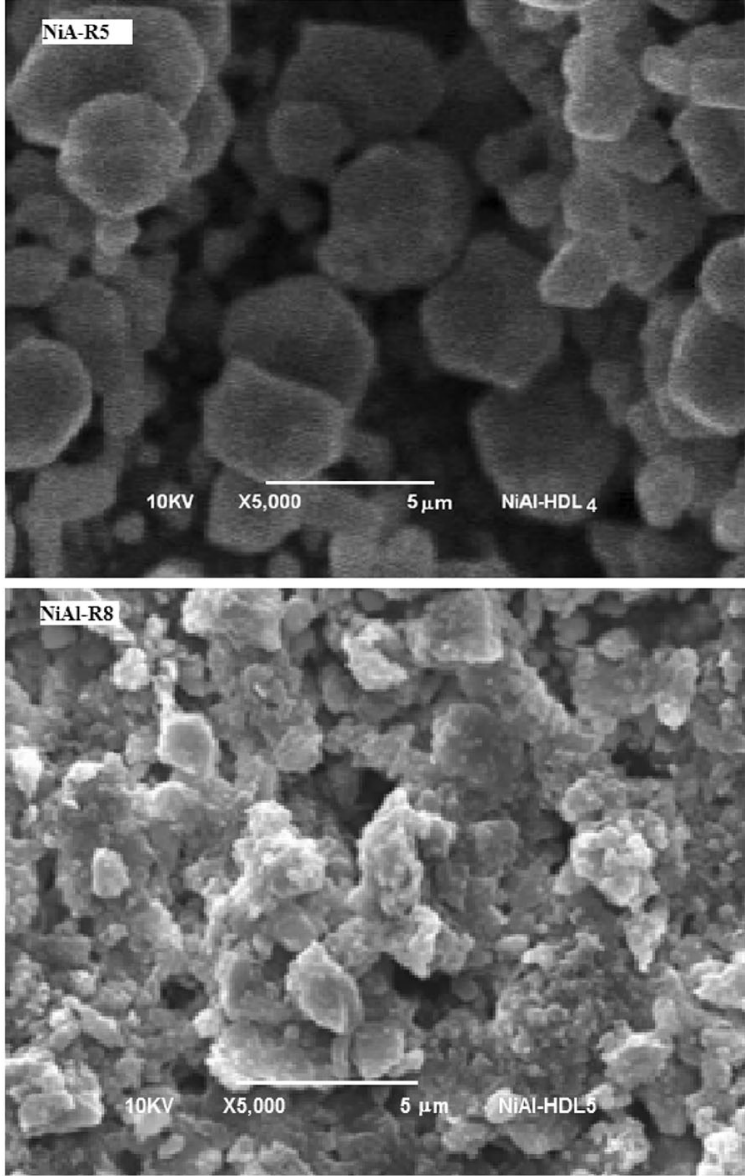


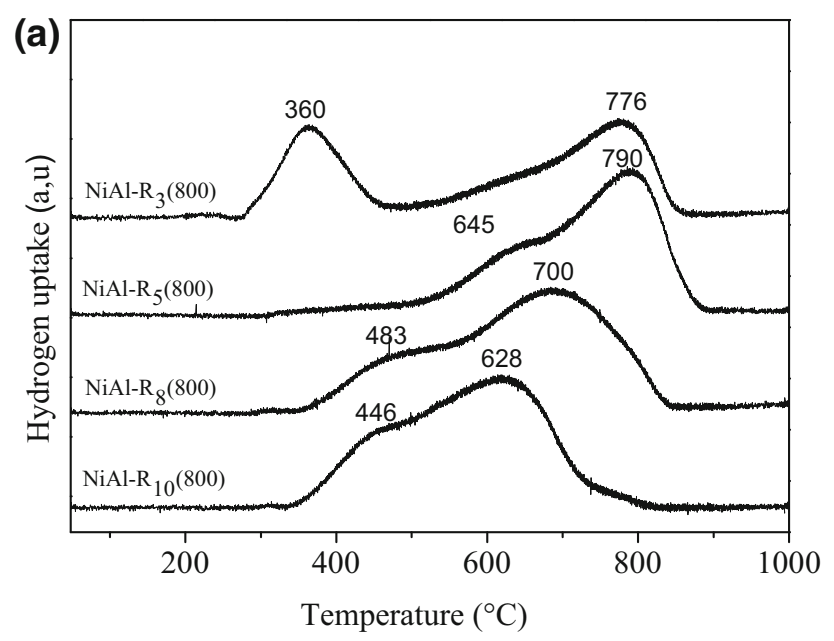

(b)

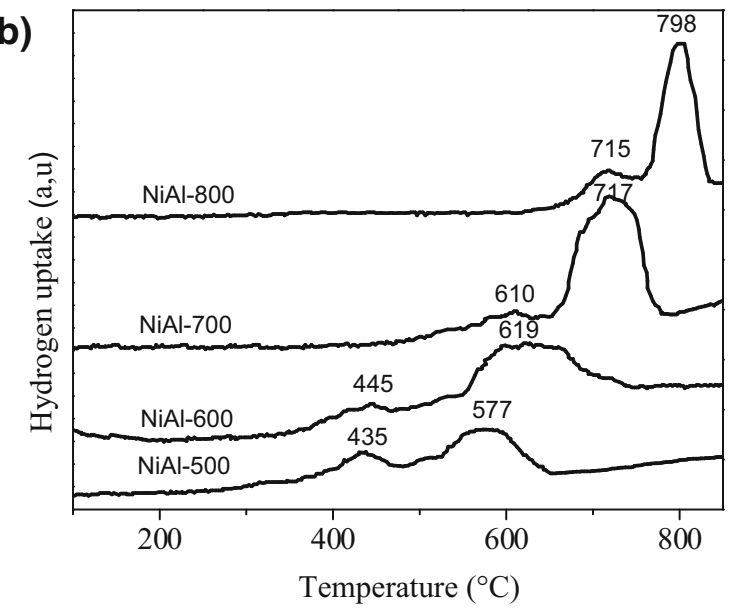

Fig. 8 Temperature-programmed reduction (TPR) of (a) NiAl$R(800)$ and (b) NiAl- $T$

constant, the reducibility decreases with an increase in the amount of aluminum.

Figure $8 \mathrm{~b}$ shows $\mathrm{TPR}$ profiles for $\mathrm{NiAl}-R_{2}$, calcined at 500, 600, 700 and $800{ }^{\circ} \mathrm{C}$. In case of NiAl-800 sample, two reduction peaks were observed. The first peak observed at $715^{\circ} \mathrm{C}$ is assigned to the reduction of $\mathrm{Ni}^{2+}$ in $\mathrm{NiO}$. The peak at $798{ }^{\circ} \mathrm{C}$ is assigned to the reduction temperature probably caused by the reduction of $\mathrm{Ni}^{2+}$ to $\mathrm{Ni}^{0}$ in $\mathrm{NiAl}_{2} \mathrm{O}_{4}$.

In summary, the dense structure of $\mathrm{NiAl}_{2} \mathrm{O}_{4}$ in NiAl$R_{2}(800)$ can stabilize $\mathrm{Ni}^{2+}$ ions, which leads to an increase in the reduction temperature. The maximum reduction temperature is shifted to lower values while there is a decrease in calcination temperature. The results indicate that higher calcination temperatures have an effect on increasing the interaction between the oxides present in the catalysts; this is probably owing to the formation of periclase $\mathrm{Al}_{2} \mathrm{O}_{3}$ and/or $\mathrm{NiAl}_{2} \mathrm{O}_{4}$ phase [49]. This reduction temperature is higher than required in pure $\mathrm{NiO}$ and is a typical feature of catalysts derived from hydrotalcites [39, 40].

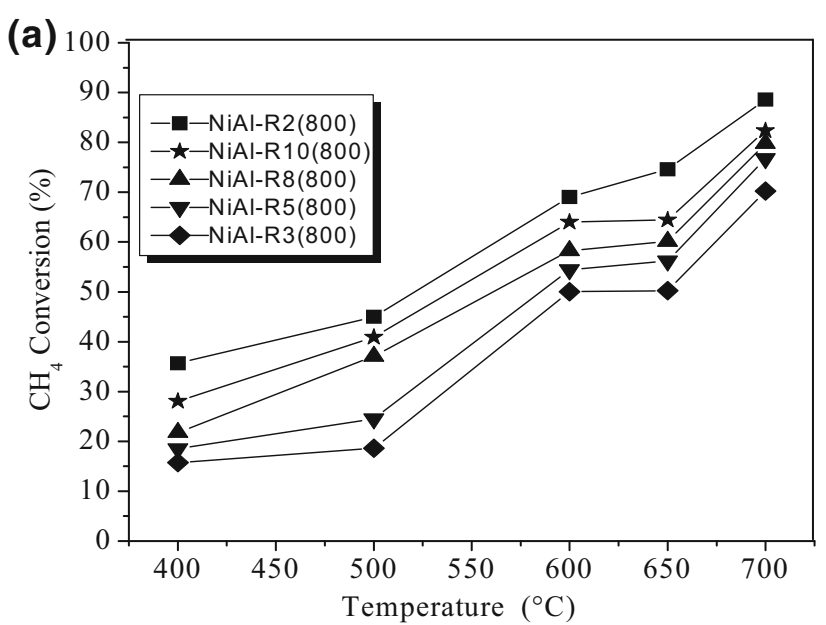

(b)

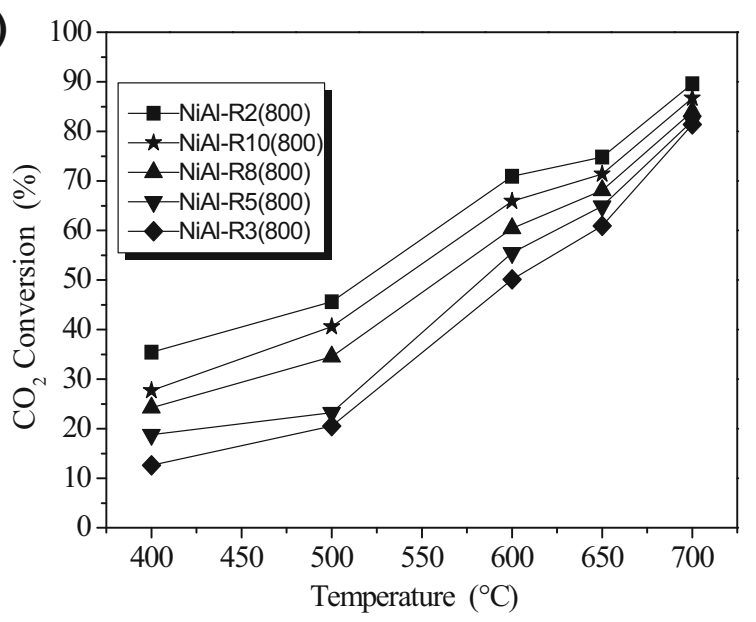

Fig. 9 Conversion of (a) methane and (b) carbon dioxide, for catalysts $\mathrm{NiAl}-R(800)$ versus temperature

\section{Catalytic tests}

The performance of NiAl- $R$ was tested in DRM reactions in the presence of equimolar amounts of methane and carbon dioxide. The reaction's temperature was gradually raised from 400 to $700{ }^{\circ} \mathrm{C}$, followed by an in situ reduction of $\mathrm{H}_{2}$ at $750{ }^{\circ} \mathrm{C}$, over a period of $1 \mathrm{~h}$. A graph showing the amount of methane and carbon dioxide conversion during the DRM process, in the presence of NiAl- $R\left(800{ }^{\circ} \mathrm{C}\right)$, at various temperatures, is presented in Fig. 9a and b. Both graphs clearly demonstrate the direct proportionality between methane and carbon dioxide conversions, and the reaction's temperature.

A plot showing the amount of conversion of methane and carbon dioxide over time, at $700{ }^{\circ} \mathrm{C}$, is also depicted in Fig. 10. The catalytic performance of our synthesized materials reaches its maxima during the first $2 \mathrm{~h}$ of the reaction, after which the amounts of methane and carbon dioxide conversion remain steady over the rest of time i.e. $8 \mathrm{~h}$. The results also indicate that the activity of the 
synthesized catalysts increases with the increase in $\mathrm{Ni} / \mathrm{Al}$ ratio (when $R>2$ ). From this relationship, it appears that the order of catalytic activity follows the sequence: NiAl$R_{2}>\mathrm{NiAl}-R_{10}>\mathrm{NiAl}-R_{8}>\mathrm{NiAl}-R_{5}>\mathrm{NiAl}-R_{3}$. According to the results presented in Table 2 , the activity of these catalysts can be attributed to the size of $\mathrm{Ni}^{0}$, and the specific surface obtained following the reduction step, with exception to $\mathrm{NiAl}-R_{2}\left(800{ }^{\circ} \mathrm{C}\right)$, where the size of $\mathrm{Ni}^{0}$ crystallites decreases with the increase in $\mathrm{Ni} / \mathrm{Al}$ ratio. Hence, the catalytic activity of our catalysts is inversely proportional to the size of $\mathrm{Ni}^{0}$ and directly proportional to the specific surface obtained after the reduction process. Previous studies also experienced similar results [40, 50]. It is worth noting that the amount of nickel used in our experiments remained unchanged throughout this project. In all cases, where $R>2$, the molar ratio of the resulting hydrogen to carbon monoxide is always less than one (Table 3); it was also observed that the amount of carbon dioxide converted is greater than that of methane. Such results might be attributed to the reverse water-gas shift reaction (Eq. 10), which also explains the higher conversion of carbon dioxide [33].

$\mathrm{CO}_{2}+\mathrm{H}_{2} \rightarrow \mathrm{CO}+\mathrm{H}_{2} \mathrm{O}$
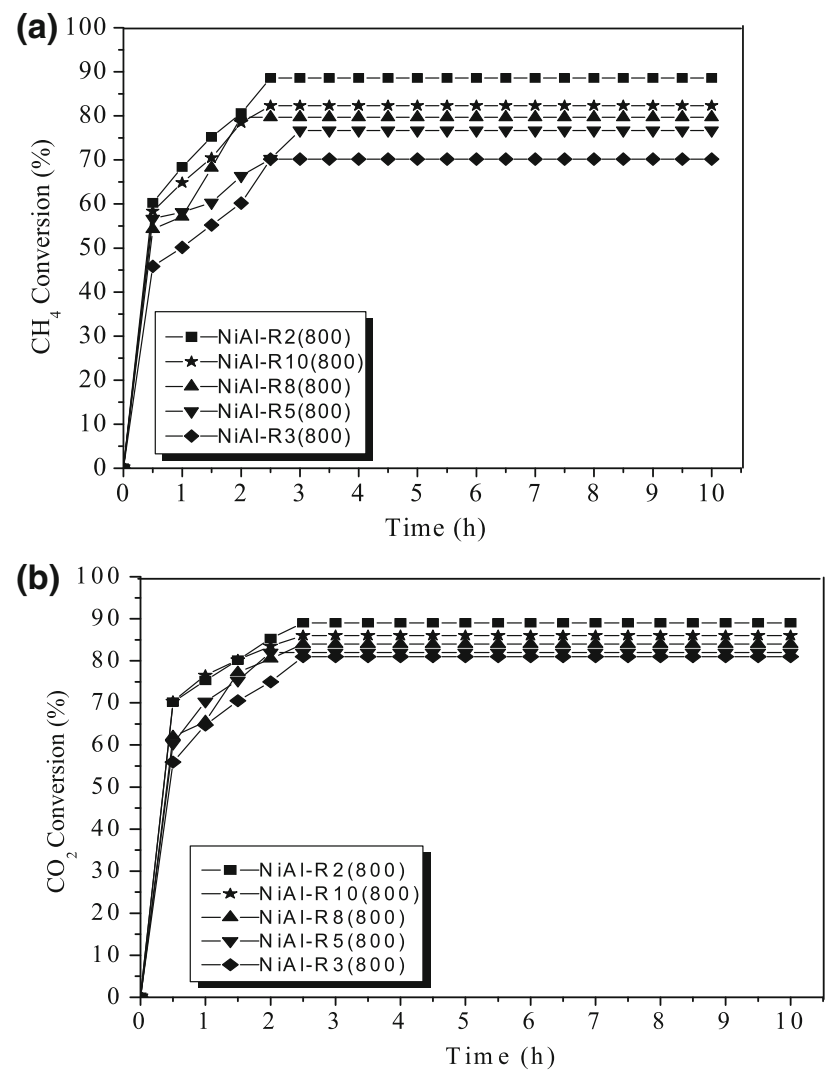

Fig. 10 Conversion of (a) methane and (b) carbon dioxide, for NiAl$R(800)$ versus time
In case of $\mathrm{NiAl}-R_{2}\left(800{ }^{\circ} \mathrm{C}\right)$, the $\mathrm{H}_{2} / \mathrm{CO}$ molar ratio was close to one (Table 3 ), while the conversion rate of carbon dioxide is equal to that of methane, which indicates a very efficient DRM reaction. The ratio of hydrogen to carbon monoxide also tends to increase in the event of decreasing the amount of aluminum; such phenomenon can be explained by the acidic character of aluminum [40]. Furthermore, it was previously claimed that in the presence of lower aluminum content, the concentration of basic sites increases in $\mathrm{Ni} / \mathrm{Mg} / \mathrm{Al}$ catalysts, this observation was specific to those with identical $\mathrm{Ni} / \mathrm{Mg}$ ratio $(\mathrm{Ni} / \mathrm{Mg}=5)$. Hence, catalysts containing low levels of aluminum tend to effect DRM reactions which produce higher hydrogen to carbon monoxide ratio. On the other hand, the presence of other Lewis acid sites in the catalyst tends to enhance the catalytic activity of the overall DRM process [28]. For example, HZSM-5 and USY zeolites, as well as $\mathrm{Ni} / \gamma$ $\mathrm{Al}_{2} \mathrm{O}_{3}$, were found to exhibit a catalytic effect strongly dependent on the acidity and reducibility of the catalyst.

The high catalytic performance of NiAl- $R_{2}\left(800^{\circ} \mathrm{C}\right)$ can be related to two parameters: (1) the low $\mathrm{Ni}^{0}$ crystallite size and (2) the high stability of the support $\left(\mathrm{NiAl}_{2} \mathrm{O}_{4}\right)$, which can maintain a very high specific surface area $\left(119 \mathrm{~m}^{2} \mathrm{~g}^{-1}\right)$ following the reduction step when compared to other catalysts such as NiAl- $R_{10} \quad\left(114 \mathrm{~m}^{2} \mathrm{~g}^{-1}\right), \quad \mathrm{NiAl}-R_{8}$ $\left(101 \mathrm{~m}^{2} \mathrm{~g}^{-1}\right), \quad \mathrm{NiAl}-R_{5} \quad\left(95 \mathrm{~m}^{2} \mathrm{~g}^{-1}\right), \quad$ and $\mathrm{NiAl}-R_{3}$ $\left(70 \mathrm{~m}^{2} \mathrm{~g}^{-1}\right)$. The resulting effect might have been due to the spinel phase formation following the reduction step, as illustrated in Table 2.

Figure 11 shows the catalytic conversion of NiAl$T\left(T=300,400,500,600,700\right.$, and $\left.800^{\circ} \mathrm{C}\right)$. Our results demonstrate that the calcination temperature has a minimal effect on the catalytic activity at temperatures less than $500{ }^{\circ} \mathrm{C}$. Table 3 also shows that the size of $\mathrm{Ni}^{\circ}$ and specific surface area after reduction remain unchanged for NiAl300 and NiAl-400. At higher calcination temperatures, the size of $\mathrm{Ni}^{0}$ shows a decreasing pattern; following reduction, the specific surface area tends to augment as calcination temperature rises.

However, for higher reaction temperatures i.e. 600, 650, and $700{ }^{\circ} \mathrm{C}$, the conversion of $\mathrm{CO}_{2}$ was higher than that of $\mathrm{CH}_{4}$, while the ratio of $\mathrm{H}_{2} / \mathrm{CO}$ was always less than one $(0.58-0.71)$. This result can be attributed to the reverse water-gas shift reaction (Eq. 10) [33].

For NiAl-600 and NiAl-700, the ratio of $\mathrm{H}_{2} / \mathrm{CO}$ was about 0.95 . This certainly indicates that such catalysts have the greatest stability, and the occurrence of reverse watergas shift is less significant. In this case, the optimum calcination temperature can be either 800,700 or $600{ }^{\circ} \mathrm{C}$. Feng et al. [32] investigated the effect of calcination temperature on the catalytic performance of $\mathrm{NiO} / \mathrm{MgO}$, prepared by impregnation and calcined at 600 and $800{ }^{\circ} \mathrm{C}$. 
Table $3 \mathrm{H}_{2} / \mathrm{CO}$ as a function of reaction temperature for the NiAl- $R(800)$ and NiAl- $T$, at reaction conditions: $P=1 \mathrm{~atm}, \mathrm{CH}_{4} / \mathrm{CO}_{2}=1$

\begin{tabular}{|c|c|c|c|c|c|}
\hline \multirow[t]{2}{*}{ The samples } & \multicolumn{5}{|c|}{ The reaction temperature } \\
\hline & $\begin{array}{l}400{ }^{\circ} \mathrm{C} \\
\mathrm{CO} / \mathrm{H}_{2}\end{array}$ & $\begin{array}{l}500{ }^{\circ} \mathrm{C} \\
\mathrm{CO} / \mathrm{H}_{2}\end{array}$ & $\begin{array}{l}600{ }^{\circ} \mathrm{C} \\
\mathrm{CO} / \mathrm{H}_{2}\end{array}$ & $\begin{array}{l}650^{\circ} \mathrm{C} \\
\mathrm{CO} / \mathrm{H}_{2}\end{array}$ & $\begin{array}{l}700{ }^{\circ} \mathrm{C} \\
\mathrm{CO} / \mathrm{H}_{2}\end{array}$ \\
\hline $\mathrm{NiAl}-300$ & 0.69 & 0.68 & 0.69 & 0.60 & 0.50 \\
\hline $\mathrm{NiAl}-400$ & 0.71 & 0.70 & 0.65 & 0.60 & 0.58 \\
\hline $\mathrm{NiAl}-500$ & 0.98 & 0.98 & 0.85 & 0.77 & 0.76 \\
\hline NiAl-600 & 1.00 & 1.00 & 0.98 & 0.95 & 0.95 \\
\hline NiAl-700 & 1.00 & 1.00 & 0.96 & 0.95 & 0.95 \\
\hline NiAl-800 & 1.00 & 1.00 & 1.00 & 0.99 & 0.98 \\
\hline $\mathrm{NiAl}-R_{3}(800)$ & 0.94 & 0.90 & 0.89 & 0.89 & 0.84 \\
\hline $\mathrm{NiAl}-R_{5}(800)$ & 0.96 & 0.91 & 0.90 & 0.90 & 0.89 \\
\hline $\mathrm{NiAl}-R_{8}(800)$ & 0.97 & 0.94 & 0.92 & 0.92 & 0.91 \\
\hline $\mathrm{NiAl}-R_{10}(800)$ & 0.98 & 0.95 & 0.93 & 0.93 & 0.93 \\
\hline $\mathrm{NiAl}-R_{2}(800)$ & 1.00 & 1.00 & 1.00 & 0.99 & 0.98 \\
\hline
\end{tabular}
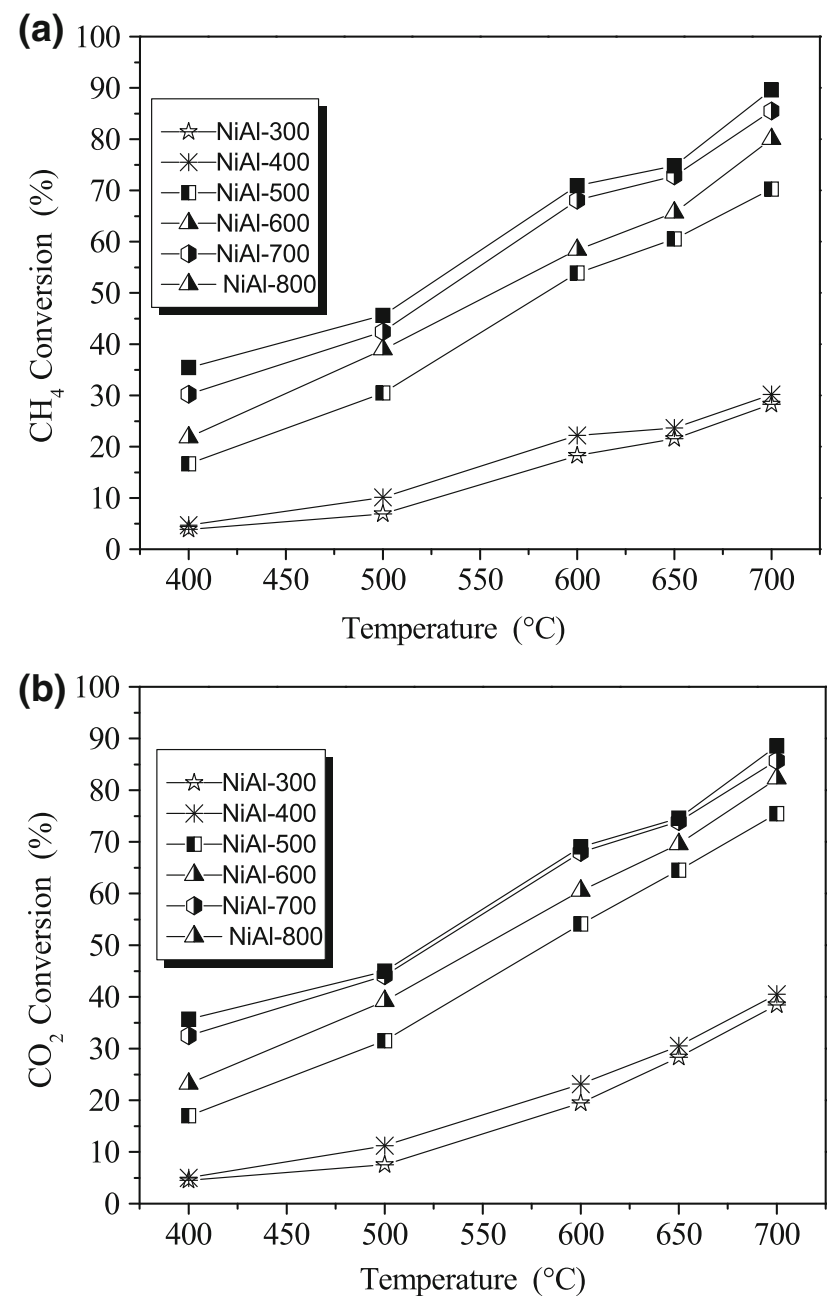

Fig. 11 Conversion of (a) methane and (b) carbon dioxide for NiAl$T$ versus temperature
Their results indicated that $\mathrm{NiO} / \mathrm{MgO}$ catalysts calcined at $800{ }^{\circ} \mathrm{C}$ displayed stronger interactions between the metal and the support, as well as exhibited higher activities.

The effect of calcination temperature on the activity of alumina supported nickel $\left(\mathrm{Ni} / \gamma-\mathrm{Al}_{2} \mathrm{O}_{3}\right)$ catalyst in DRM reactions was also studied by $\mathrm{Al}$-Fatesh and co-workers [51].

At calcination temperatures of 500, 600, 700 and $800{ }^{\circ} \mathrm{C}$, it has been shown that increasing the temperature also enhances the catalysts' activity. The highest conversion was obtained at $800{ }^{\circ} \mathrm{C}$ in the presence of a catalyst calcined at $900{ }^{\circ} \mathrm{C}$ and activated at $700{ }^{\circ} \mathrm{C}$.

In previous work, Perez-Lopez et al. [40] have studied the influence of the calcination temperature on $\mathrm{Ni}-\mathrm{Mg}-\mathrm{Al}$ catalysts in DRM reactions performed between 500 and $700{ }^{\circ} \mathrm{C}$. The effect of calcination temperature on the catalysts' activity is smaller and practically does not affect the conversion of methane; however, its influence is only limited to the specific surface area.

\section{Conclusions}

Hydrotalcite-like precursors NiAl- $R(R=2,3,5,8$ and 10$)$ were successfully synthesized using co-precipitation at $\mathrm{pH}=12$, and calcined at different temperatures. XRD of the synthesized materials clearly demonstrated the hydrotalcite-like structure of all samples where $R \leq 5$. After calcination of NiAl-T $(T=300,400,500,600$, and $700{ }^{\circ} \mathrm{C}$ ) as well as NiAl- $R_{3}, \mathrm{NiAl}-R_{5}, \mathrm{NiAl}-R_{8}$ and NiAl$R_{10}$, calcined at $800{ }^{\circ} \mathrm{C}$, the lamellar structure disappears and only $\mathrm{NiO}$ phase is observed. The spectrum of $\mathrm{NiAl}-R_{2}$, calcined at $800{ }^{\circ} \mathrm{C}$, shows two series of broad peaks 
corresponding to reflections close to those of $\mathrm{NiO}$ and $\mathrm{NiAl}_{2} \mathrm{O}_{4}$ spinel phases. The best catalytic results for DRM reactions were obtained with $\mathrm{NiAl}-R_{2}$, where values of conversion and selectivity were near thermodynamic equilibrium at $700{ }^{\circ} \mathrm{C}$. The high performance of the catalytic process can be attributed to the lower size of nickel, and the high stability of the support $\left(\mathrm{NiAl}_{2} \mathrm{O}_{4}\right)$. This shall equally maintain a very high specific surface area following the reduction step.

Acknowledgments The authors would like to thank warmly Dr Rafika IKKENE for her comments on this work and for the thrilling discussions we had during the preparation of this article.

Open Access This article is distributed under the terms of the Creative Commons Attribution 4.0 International License (http:// creativecommons.org/licenses/by/4.0/), which permits unrestricted use, distribution, and reproduction in any medium, provided you give appropriate credit to the original author(s) and the source, provide a link to the Creative Commons license, and indicate if changes were made.

\section{References}

1. Li H, Wang $\mathrm{J}$ (2004) Study on $\mathrm{CO}_{2}$ reforming of methane to syngas over $\mathrm{Al}_{2} \mathrm{O}_{3}-\mathrm{ZrO}_{2}$ supported $\mathrm{Ni}$ catalysts prepared via a direct sol-gel process. Chem Eng Sci 59:4861-4867

2. Hu J, Yu F, Lu Y (2012) Application of Fischer-Tropsch synthesis in biomass to liquid conversion. Catal 2:303-326. doi:10. 3390/catal2020303

3. Ferreira-Aparicio P, Rodriguez-Ramos I, Anderson JA, GuerroroRuiz A (2000) Mechanistic aspects of the dry reforming of methane over ruthenium catalysts. Appl Catal 202:183-196

4. Batiot-Dupeyrat C, German ASG, Mondragon F, Barrault J, Tatibouet JM (2005) $\mathrm{CO}_{2}$ reforming of methane over $\mathrm{LaNiO}_{3}$ as precursor material. Catal Today 107-108:474-480

5. Djaidja A, Libs S, Kiennemann A, Barama A (2006) Characterization and activity in dry reforming of methane on $\mathrm{NiMg} / \mathrm{Al}$ and $\mathrm{Ni} / \mathrm{MgO}$ catalysts. Catal Today 113:194-200

6. Gaur S, Haynes DJ, Spivey JJ (2011) Rh, Ni, and Ca substituted pyrochlore catalysts for dry reforming of methane. Appl Catal A Gen 403:142-151

7. Benrabaa R, Lofberg A, Rubbens A, Bordes-Richard E, Vannier RN, Barama A (2013) Structure, reactivity and catalytic properties of nanoparticles of nickel ferrite in the dry reforming of methane. Catal Today 203:188-195

8. Nurunnabi M, Li B, Kunimori K, Suzuki K, Fujimoto KI, Tomishige K (2005) Performance of $\mathrm{NiO}-\mathrm{MgO}$ solid solutionsupported Pt catalysts in oxidative steam reforming of methane. Appl Catal A 292:272-280

9. Özkara-Aydınoglu S, Özensoy E, Aksoylu AE (2009) The effect of impregnation strategy on methane dry reforming activity of Ce promoted $\mathrm{Pt} / \mathrm{ZrO}_{2}$. Int J Hydrogen Energy 34:9711-9722

10. Moradi GR, Khosravian F, Rahmanzadeh M (2012) Effects of partial substitution of $\mathrm{Ni}$ by $\mathrm{Cu}$ in $\mathrm{LaNiO}_{3}$ perovskite catalyst for dry methane reforming. Chin J Catal 33:797-801

11. Su YJ, Pan KL, Chang MB (2014) Modifying perovskite-type oxide catalyst $\mathrm{LaNiO}_{3}$ with $\mathrm{Ce}$ for carbon dioxide reforming of methane. Int J Hydrogen Energy 39:4917-4925

12. Benrabaa R, Boukhlouf H, Lofberg A, Rubbens A, Vannier RN, Bordes-Richard E, Barama A (2012) Nickel ferrite spinel as catalyst precursor in the dry reforming of methane: synthesis, characterization and catalytic properties. J Nat Gas Chem 21:595-604

13. Christensen KO, Chen D, Lodeng R, Holmen A (2006) Effect of supports and Ni crysal size on carbon formation and sintering during steam methane reforming. Appl Catal A Gen 314:9-22

14. Bhattacharyya A, Chang VW, Schumacher DJ (1998) $\mathrm{CO}_{2}$ reforming of methane to singas I: evaluation of hydrotalcite clayderived catalysts. Appl Clay Sci 13:317-328

15. Basile F, Fornasari G, Poluzzi E, Vaccari A (1998) Catalytic partial oxidation and $\mathrm{CO}_{2}$ reforming on Rh- and Ni-based catalysts obtained from hydrotalcite-type precursors. Appl Clay Sci 13:329-345

16. Bashi AM, Haddawi SM, Mezaal MA (2013) Layered double hydroxides nanohybrid intercalation with folic acid used as delivery system and their controlled release properties. Arab J Sci Eng 38:1663-1680

17. Zhao S, Yi H, Tang X, Kang D, Wang H, Li K, Duan K (2012) Characterization of $\mathrm{Zn}-\mathrm{Ni}-\mathrm{Fe}$ hydrotalcite-derived oxides and their application in the hydrolysis of carbonyl sulfide. Appl Clay Sci 56:84-89

18. Cantrell DG, Gillie LG, Lee AF, Wilson K (2005) Structurereactivity correlations in $\mathrm{MgAl}$ hydrotalcite catalysts for biodiesel synthesis. Appl Catal A Gen 287:183-190

19. Baskaran T, Christopher J, Ajithkumar TG, Sakthivel A (2014) SBA-15 intercalated $\mathrm{Mg}-\mathrm{Al}$ hydrotalcite: an environmental friendlycatalyst for hydroisomerization of olefin. Appl Catal A Gen 488:119-127

20. McKenzie AL, Fishel CT, Davis RJ (1992) Investigation of the surface structure and basic properties of calcined hydrotalcites. J Catal 138:547-561

21. Roelofs J, van Dillen AJ, de Jong KP (2000) Base-catalyzed condensation of citral and acetone at low temperature using modified hydrotalcite catalysts. Catal Today 60:297-303

22. Cantrell DG, Gillie LG, Lee AF, Wilson K (2005) Structurereactivity correlations in $\mathrm{MgAl}$ hydrotalcite catalysts for biodiesel synthesis. Appl Catal A Gen 287:183-190

23. López-Salinas E, García-Sánchez M, Montoya JA, Acosta DR, Abasolo JA, Schifter I (1997) Structural characterization of

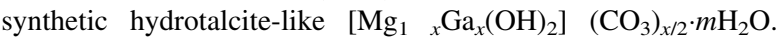
Langmuir 13:4748

24. Legrand L, Abdelmoula M, Géhin A, Chaussé A, Génin JMR (2001) Electrochemical formation of a new Fe(II) Fe(III) hydroxy-carbonate green rust: characterisation and morphology. Electrochim Acta 46:1815-1822

25. Vaccari A (1999) Clays and catalysis; a promising future. Appl Clay Sci 14:161-198

26. Xu ZP, Zhang J, Adebajo MO, Zhang H, Zhou C (2011) Catalytic applications of layered double hydroxides and derivatives. App Clay Sci 53:139-150

27. Choy JH, Jung JS, Oh JM, Park M, Jeong J, Kang YK, Han OJ (2004) Layered double hydroxide as an efficient drug reservoir for folate derivatives. Biomaterials 25:3059-3064

28. Halliche D, Cherifi O, Auroux A (2005) Microcalorimetric studies and methane reforming by $\mathrm{CO}_{2}$ on Ni-based zeolite catalysts. Thermochim Acta 434:125-131

29. Debecker DP, Gaigneaux EM, Busca G (2009) Exploring, tuning and exploiting the basicity of hydrotalcites for applications in heterogeneous catalysis. J Chem Eur 15:3920-3935

30. Beaudot P, de Roy ME, Besse JP (2004) Intercalation of noble metal complexes in LDH compounds. J Sol Stat Chem 177:2691-2698

31. You Y, Zhao H, Vance GF (2002) Adsorption of dicamba (3, 6-dichoro-2-methoxybenzoic acid) in aqueous solution by calcined- layered double hydroxides. Appl Clay Sci 21:217-226

32. Feng J, Ding YJ, Guo YP, Li X, Li WY (2013) Calcination temperature effect on the adsorption and hydrogenated dissociationof $\mathrm{CO}_{2}$ over the $\mathrm{NiO} / \mathrm{MgO}$ catalyst. Fuel 109:110-115 
33. Djebarri B, Gonzalez-Delacruz VM, Halliche D, Bachari K, Saadi A, Caballero A, Holgado JP, Cherifi O (2014) Promoting effect of $\mathrm{Ce}$ and $\mathrm{Mg}$ cations in $\mathrm{Ni} / \mathrm{Al}$ catalysts prepared from hydrotalcites for the dry reforming of methane. Reac Kinet Mech Cat 111:259-275

34. Tsyganok AI, Tsunoda T, Hamakawa S (2003) Dry reforming of methane over catalysts derived from nickel-containing $\mathrm{Mg}$-Al layered double hydroxides. J Catal 213:191-203

35. Zhang X, Wang N, Xu Y, Yin Y, Shang S (2014) A novel Ni$\mathrm{Mg}-\mathrm{Al}-\mathrm{LDHs} / \gamma-\mathrm{Al}_{2} \mathrm{O}_{3}$ catalyst prepared by in situ synthesis method for $\mathrm{CO}_{2}$ reforming of $\mathrm{CH}_{4}$. Catal Commun 45:11-15

36. Zhao L, Li X, Qu Z, Zhao Q, Liu S, Hu X (2011) The NiAl mixed oxides: the relation between basicity and $\mathrm{SO}_{2}$ removal capacity. Sep Purif Technol 80:345-350

37. Ferreira OP, Alves OL, Gouveia DX, Souza Filho AG, de Paiva JAC, Filho JM (2004) Thermal decomposition and structural reconstruction effect on $\mathrm{Mg}-\mathrm{Fe}$ based hydrotalcite compounds. J Solid State Chem 177:3058-3069

38. Bolognini M, Cavani F, Scagliarini D, Flego C, Perego C, Saba $\mathrm{M}$ (2003) Mg/Al mixed oxides prepared by coprecipitation and sol-gel routes: a comparison of their physico-chemical features and performances in m-cresol methylation. Microporous Mesoporous Mater 66:77-89

39. Guil-López R, La Parola V, Penã MA, Fierro JLG (2012) Evolution of the Ni-active centres into ex hydrotalcite oxide catalysts during the COx-free hydrogen production by methane decomposition. Int J Hydrogen Energy 37:7042-7055

40. Perez-Lopez OW, Senger A, Marcilo NR, Lansarin MA (2006) Effect of composition and thermal pretreatment on properties of $\mathrm{Ni}-\mathrm{Mg}-\mathrm{Al}$ catalysts for $\mathrm{CO}_{2}$ reforming of methane. Appl Catal A Gen 303:234-244

41. Ma W, Zhao N, Yang G, Tian L, Wang R (2011) Removal of fluoride ions from aqueous solution by the calcination product of $\mathrm{Mg}-\mathrm{Al}-\mathrm{Fe}$ hydrotalcite-like compound. Desalination 268:20-26

42. Cesteros Y, Salagre P, Medina F, Sueiras JE, Tichit D, Coq B (2001) Hydrodechlorination of 1,2,4-trichlorobenzene on nickel- based catalysts prepared from several $\mathrm{Ni} / \mathrm{Mg} / \mathrm{Al}$ hydrotalcite-like precursors. Appl Catal B Environ 32:25-35

43. Titulaer MK, Jansen JBH, Geus JW (1994) The quantity of reduced nickel in synthetic takovite: effects of preparation conditions and calcination temperature. Clays Clay Miner 42:249-258

44. Aramendia MA, Borau V, Jiménez C, Marinas JM, Ruiz JR, Urbano FJ (2002) Comparative study of $\mathrm{Mg} / \mathrm{M}(\mathrm{III})(\mathrm{M}=\mathrm{Al}, \mathrm{Ga}$, In) layered double hydroxides obtained by coprecipitation and the sol-gel method. J Solid State Chem 168:156-161

45. Othman MR, Rasid NM, Fernando WJN (2006) Mg-Al hydrotalcite coating on zeolites for improved carbon dioxide adsorption. Chem Eng Sci 61:1555-1560

46. Li F, Zhang LH, Evans DG, Forano C, Duan X (2004) Structure and thermal evolution of mg-al layered double hydroxide containing interlayer organic glyphosate anions. ThermochimicaActa 424:15-23

47. Perez-ramirez J, Mul G, Moulijin JA (2001) In situ Fourier transform infrared and laser Raman spectroscopic study of the thermal decomposition of $\mathrm{Co}-\mathrm{Al}$ and $\mathrm{Ni}-\mathrm{Al}$ hydrotalcites. Vib Spectrosc 27:75-88

48. Guo J, Lou H, Zhao H, Chai D, Zheng X (2004) Dry reforming of methane over nickel catalysts supported on magnesium aluminate spinels. Appl Catal A Gen 273:75-82

49. González AR, Asencios YJO, Assaf EM, Assaf JM (2013) Dry reforming of methane on $\mathrm{Ni}-\mathrm{Mg}-\mathrm{Al}$ nano-spheroid oxide catalysts prepared by the sol-gel method from hydrotalcite-like precursors. Appl Surf Sci 280:876-887

50. Long H, Xu Y, Zhang X, Hu S, Shang S, Yin Y, Dai X (2013) Ni$\mathrm{Co} / \mathrm{Mg}-\mathrm{Al}$ catalyst derived from hydrotalcite-like compound prepared by plasma for dry reforming of methane. J Eng Chem 22:733-739

51. Al-Fatesh AS, Fakeeha AH (2012) Effects of calcination and activation temperature ondry reforming catalysts. J Saudi Chem Soc 16:55-61 